\title{
Widening Participation in Medicine: The Impact of Medical Student-Led Conferences for Year 12 Pupils [Letter]
}

\author{
Sulaiman Hayat (iD \\ King's College London, GKT School of \\ Medical Education, London, UK
}

Correspondence: Sulaiman Hayat King's College London, GKT School of Medical Education, London, SEI 9RT, UK Email sulaiman.hayat@kcl.ac.Uk

\section{Dear editor}

I read with great interest the paper by Ryan et al looking at the impact of a widening participation (WP) initiative for year 12 pupils. ${ }^{1}$ The study found that two medical student led conferences with appropriate mentoring for students significantly increased their confidence with regards to becoming a doctor amongst other domains. As a medical student at King`s College London I would like to congratulate the conference organisers for planning and executing the concept and I would like to offer my perspective as a London based student.

WP initiatives can be broadly divided into those aimed at the pre-application, application, and post application stages of the undergraduate application process. ${ }^{2}$ Universities run WP initiatives for their medical degree programmes, for example King`s College London runs an extended medical degree programme aimed primarily at state-school educated pupils which has been running for two decades. ${ }^{3}$ Therefore, it is no surprise that this has been followed by medical student led initiatives in this field like the ones done by Ryan et al.

The study by Ryan et al measured the impact of their interventions on various domains by using confidence scores before and after the events. However, no domain looked at confidence changes with regards to approaching the actual application process. In the future it would be useful to analyse the impact of such interventions on student confidence in taking the university admissions tests as this is a crucial part of the process. Indeed, a multi-cohort study found that students from independent schools had higher entry test scores on the University Clinical Aptitude test (UCAT) ${ }^{4}$ However, the state school students in this study were twice as likely to finish in the $10 \%$ of their graduating cohort. This suggests that the inequality in performance is greater before university and is levelled up to some extent by the end of the course. Therefore, more focus is required to support such students at the admissions stage, and it is vital to look at the effect of WP interventions at this stage.

The study by Ryan et al used certain WP flags as inclusion criteria for one of the conferences. Surprisingly students whose parents are in the medical profession are over 20 times more likely to become doctors compared to students whose parents aren't in the profession. ${ }^{5}$ Perhaps this can justify having one of the WP flags as "no doctors in the immediate family" in future studies. Amongst numerous benefits, 
parents as doctors can provide easy routes into work experience which is desirable by universities. Therefore, going forwards we need to work to increase the confidence of students who think they are unlikely to be successful just because there are no doctors in the family.

Overall, the work done by the study authors is particularly commendable and provides a catalyst for change. But going forwards more work needs to be done to address the above-mentioned issues because medical students are in a unique position to mentor junior students as they have recently been through the whole admissions process.

\section{Disclosure}

The author reports no conflicts of interest in this communication.

\section{References}

1. Ryan B, Auty C, Maden M, Leggett A, Staley A, Haque E. Widening participation in medicine: the impact of medical student-led conferences for year 12 pupils. Adv Med Educ Pract. 2021;12:937-943. doi:10.2147/AMEP.S314581

2. Patterson R, Price J. Widening participation in medicine: what, why and how? MedEdPublish. 2017;6(4):15. doi:10.15694/mep.2017.00 0184

3. Extended medical degree programme - King's College London [Internet]. Kcl.ac.uk. 2021 [cited 4 September 2021.]. Available from: https://www.kcl.ac.uk/study/undergraduate/courses/extendedmedical-degree-programme-mbbs. Accessed August 10, 2021.

4. Kumwenda B, Cleland JA, Walker K, et al. The relationship between school type and academic performance at medical school: a national, multi-cohort study. BMJ Open. 2017;7(8):e016291. doi:10.1136/bmjopen-2017-016291

5. Jonsson JO, Di Carlo M, Brinton MC, Grusky DB, Pollak R. Microclass mobility: social reproduction in four countries. AJS. 2009;114(4):977-1036. doi:10.1086/596566 PMID: 19824 300 .

Dove Medical Press encourages responsible, free and frank academic debate. The content of the Advances in Medical Education and Practice 'letters to the editor' section does not necessarily represent the views of Dove Medical Press, its officers, agents, employees, related entities or the Advances in Medical Education and Practice editors. While all reasonable steps have been taken to confirm the content of each letter, Dove Medical Press accepts no liability in respect of the content of any letter, nor is it responsible for the content and accuracy of any letter to the editor.

\section{Publish your work in this journal}

Advances in Medical Education and Practice is an international, peerreviewed, open access journal that aims to present and publish research on Medical Education covering medical, dental, nursing and allied health care professional education. The journal covers undergraduate education, postgraduate training and continuing medical education including emerging trends and innovative models linking education, research, and health care services. The manuscript management system is completely online and includes a very quick and fair peer-review system. Visit http://www.dovepress.com/testimonials.php to read real quotes from published authors. 